\title{
SCOTTISH SNOW CONDITIONS
}

IN 1939 it was decided to leave a book in the Ben Nevis Hut in order that visitors might record the snow conditions there. The Scottish Mountaineering Club gave the necessary permission and much help. The register was brought down early in 1946 , inspected and returned to the hut for further entries.

Mr. L. C. W. Bonacina has written the following provisional report:

\section{Report on the register left at the Ben Nevis Hut}

This is a useful record and the register should be returned to Ben Nevis as the entries over a long period would prove really valuable.

The present entries are, of course, fragmentary and not all of equal value; but making allowance for these defects two interesting indications emerge :

I. Ben Nevis is high enough for the seasonal factor in snowfall accumulation to be apparent -with a maximum depth towards late spring, but low enough for the influence of severe spells of weather at any time between autumn and spring also to be apparent in the observations.

2. It is clear that large quantities of snow are blown from the summit and this is probably the crucial factor in preventing the growth of a small firn field at the present time.

The Cairngorms in April 1946

Mr. R. G. Sandeman sends a report of which the following is a summary:

There was less snow than usual in April owing to a good winter and the absence of heavy falls. The snow slopes in corries were generally in good condition for climbing and the snow in some gullies was ice-hard. There were no large cornices.

There was no continuous covering of snow except on a few days when new snow had fallen during the night. The Scottish Ski Club meet at Easter found poor conditions, the only runs being down a few slopes in stream beds. There was a good deal of bad weather with fierce blizzards. I found much less snow than in April 1939 when I paid my last visit to the Cairngorm and found deep and continuous snow right down to low ground. An ascent of Braeriach on April 5 proved extremely difficult on account of the deep new snow. April is not the month to examine the socalled permanent snow beds in the Cairngorms because there is far too much snow at that season; September or August would be the best months.

\section{THE HARDNESS OF ICE AND AERIAL EROSION}

MANY authorities have demonstrated that the hardness of ice varies inversely as the temperature, which is, of course, to be expected by analogy with metals. Recently Dr. E. Blackwelder ${ }^{1}$ caused some experiments to be made at a temperature of $-78.5^{\circ} \mathrm{C}$., the temperature of solid carbon dioxide. At this temperature the hardness of ice was found to be approximately 6 , or that of orthoclase felspar. Hitherto it had been assumed that aerial corrosion of rocks close to glaciers and snowfields was in the main due to rock dust. It now seems likely that when air temperatures fall very low, as for instance during blizzards, ice fragments or snow could abrade certain limestones and shales and even some igneous rocks. Ice and snow may therefore play a more important part in aerial erosion than had been suspected.

${ }^{1}$ Am. Fourn. Science, Vol. 238 , 1940, pp. 61-2. 